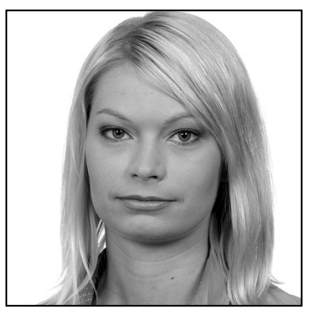

Mari Schihalejev

Doctoral Student

University of Tartu

\title{
Formation of Creditor Groups in Reorganisation Proceedings: Does Estonia Need a Better Regulation?
}

\section{Introduction}

The objective of reorganisation proceedings is to enable enterprises to restore their liquidity, improve their profitability, and ensure their sustainable management. The Estonian Reorganisation Act ${ }^{*_{1}}$ (RA) entered into force on 26 December 2008. Since there was no similar regulation in Estonia before, no widespread court practice can be cited; however, it is clear that for some questions the existing law does not provide optimal regulation. In its Submission for Approval of the Plan of Developing the Draft Act on Amending the Reorganisation Act ${ }^{*_{2}}$, the Estonian Ministry of Justice has drawn attention specifically to the problem that the effectiveness of reorganisation proceedings is low. One way to bring greater effectiveness is to ensure protection of the rights of the debtor and creditors alike. This refers to the law having to enable companies to have the opportunity for reorganisation, if it is reasonable, and having to preclude the possibility of general rights of creditors not being protected against abuse by creditors with special interests. As the creditors have to accept the reorganisation plan, one means for reaching the objectives of reorganisation proceedings is division of creditors into several voting groups. The associated issue has been noted in the above-mentioned plan and had also been underscored earlier in the legal literature. ${ }^{*} 3$

The main problem related to creditor groups is that the RA does not oblige the debtor to designate individual creditor groups and makes no special provisions for pledgees or debtor-related persons. This means that the debtor is able to manipulate the votes in order to ensure the acceptance of the plan. According to the RA's §24 (1), creditors shall decide on acceptance of a reorganisation plan by means of voting. According to $\$ 21$ (2) of the RA, this reorganisation plan may prescribe that the claims of creditors shall be satisfied separately, by creditor group. Creditors with the same rights constitute one group. However, it is unclear what is meant by 'the same rights'. The provisions regulating the voting process do not prescribe definitive instructions. The RA does not specify clearly which creditors should be divided into distinct groups. Nor does the RA even state the minimum requirements applicable in those situations in which creditors shall

Saneerimisseadus. - RT I 2008, 53, 296; RT I, 21.12.2012, 1 (in Estonian).

2 Saneerimisseaduse muutmise seaduse eelnõu väljatöötamiskavatsuse esitamine kooskõlastamiseks ['Submission for Approval of the Plan of Developing the Draft Act on Amending the Reorganisation Act']. Available at http://eelnoud.valitsus.ee/ main\#QZDoekBD (most recently accessed on 5.1.2014) (in Estonian).

3 P. Varul. Maksejõuetuse areng Eestis ['Developments in insolvency law in Estonia']. - Juridica 2013/4, p. 238 (in Estonian). 
be divided into separate groups. Neither has the Supreme Court provided clear guidelines about the formation of creditor groups. In case 3-2-1-25-11, the Supreme Court stated that if creditors with various rights are treated significantly differently in the plan, the creation of groups is compulsory. ${ }^{*} 4$ However, it is still unclear in which cases creditor groups should be formed and in which cases the formation of groups is not allowed.

Consequently, under current insolvency law, the debtor has an extensive right of discretion to form creditor groups in such a way as to ensure the acceptance of the reorganisation plan. The formation of the groups is a key issue in reorganisation proceedings. However, in some cases, the formation of the groups is not legitimate and does not correspond to the rights and interests of at least some of the creditors. Therefore, creditors vote against the reorganisation plan and there is no quorum for the acceptance of the reorganisation plan. According to §24 of the RA (Subsection 4), if creditors are divided into groups on the basis of a reorganisation plan, the plan shall be accepted if, for each group, at least half of the creditors belonging to that group vote in favour of the reorganisation plan and at least two thirds of all votes represented in the group are cast in favour of it. If the formation of groups does not correspond to the creditors' rights and interests, creditors will vote against the acceptance of a reorganisation plan; therefore, with the plan proposed not adopted, the reorganisation proceedings fail. Consequently, the debtor in such cases shall file a bankruptcy petition because of having no opportunity to overcome the economic difficulties by means of reorganisation proceedings.

To safeguard the parties' interests and ensure the legality of the voting in the proceedings, it has been prescribed that creditors who have the same rights and interests should vote in a different group from those with a different general set of rights and interests. The International Working Group on European Insolvency Law has set forth principles of European insolvency law according to which the persons affected by a reorganisation plan should vote in separate categories. ${ }^{*}$ Several international organisations have also given instructions about dividing creditors into distinct groups for voting purposes. The principles and guidelines of the World Bank ${ }^{* 6}$ and UNCITRAL ${ }^{*} 7$ prescribe that the law should provide regulations on the formation of creditor groups. Furthermore, in a number of countries that have a long-standing tradition of reorganisation proceedings it is compulsory to cluster creditors into groups (examples are the United States, Germany, and Finland).

In current Estonian practice, debtors rarely form creditor groups for voting purposes in such a way as would be consistent with the creditors' rights and interests. Doing so, however, would ensure equal treatment for the creditors while also protecting the interests and rights of the debtor. Accordingly, creditors would be interested in voting and in the adoption of a reorganisation plan, which means that the enterprise seeking restructuring could continue its economic activity.

The main problem of Estonian law as it currently stands seems to be, in fact, that the law does not provide clear rules about forming of creditor groups. Therefore, the issue arises of whether the law provides sufficient protection to the parties to reorganisation proceedings. The question is this: should the law provide for formation of separate creditor groups for voting purposes in order to ensure the protection of the parties' rights and interests? There is a second question too: which creditors should be defined as forming a separate group for voting purposes in reorganisation proceedings?

4 CCSCr 9.5.2011, 3-2-1-25-11, para. 40. Available at http://www.riigikohus.ee/?id=11\&tekst=RK/3-2-1-25-11 (most recently accessed on 5.1.2014) (in Estonian).

5 B. Wessels. Principles of European Insolvency Law. Vrije University Amsterdam, p. 7. Available at http://www.iiiglobal.org/ component/jdownloads/finish/39/405.html (most recently accessed on 5.1.2014).

6 The World Bank. Principles and Guidelines for Effective Insolvency and Creditor Rights Systems. April 2001, p. 11. Available at http://www.worldbank.org/ifa/ipg_eng.pdf (most recently accessed on 5.1.2014).

7 United Nations Commission on International Trade Law (UNCITRAL). Legislative Guide on Insolvency Law, pp. 262-263, 275. Available at http://www.uncitral.org/pdf/english/texts/insolven/o5-80722_Ebook.pdf (most recently accessed on 26.1.2014). 


\section{The objective in the formation of creditor groups and legislation in other countries}

Reorganisation proceedings are categorised as a type of collective insolvency proceedings. This means that, as in bankruptcy proceedings, the principle of equal treatment of creditors applies. ${ }^{* 8}$ It has been held in the legal literature that the notion of equality of creditors is understood today as referring to procedural equality. ${ }^{*}$ In this view, each creditor should have the same opportunity to participate in reorganisation proceedings. This principle is relevant for several aspects of the proceedings, including the voting process. However, it has been declared, not all creditors have to be treated identically. ${ }^{*} \mathrm{In}$ fact, creditors who differ in their rights and interests should not vote in the same group. No matter the wish to treat all creditors equally, full applicability of the above-mentioned principle has been deemed impossible in the literature. ${ }^{* 11}$ It has been held that deviations are caused by various historical, political, and pragmatic factors, among them the desire to ensure legal certainty and profitability of the debtor's activities. ${ }^{*}{ }^{12}$ One of the important deviations would be the following: pledgees and debtor-related persons would vote in different groups relative to other creditors. Deviations from the above-mentioned principle have been caused by the fact that pledgees and debtor-related persons differ in their rights and interests from other creditors. The formation of groups of the mentioned creditors avoids potential conflicts of interest among the creditors. It ensures the fair treatment of creditors and the legitimacy of the voting. Moreover, creditors with the same rights are treated equally within the separate group.

Secured creditors and unsecured creditors have different rights and interests. Claims of secured creditors are secured by the pledge, which means that their claim is preferred over all other claims with respect to a pledged property. Therefore, the interests of the pledgee are associated in particular with whether the reorganisation measures affect the pledge. If the plan through its reorganisation measures affects the pledged property, the pledgee has a preferential right to the property. If all creditors vote in the same group, a situation may arise wherein unsecured creditors make decisions about pledged property that violate the principle of the strong position of the pledgee. On the other hand, when the plan does not affect the pledged property but secured creditors nonetheless have the right to vote, the interests of unsecured creditors are eroded. Secured creditors usually have the majority of votes, but if they are not interested in voting, the necessary quorum will not be reached for acceptance of the plan, even when the plan may be consistent with the interests of other creditors. It has been held in the legal literature, that voting in different creditor groups ensures that creditors cannot prevent the reorganisation plan. ${ }^{* 13}$ With distinct groups, it has also been declared, that it will be easier to achieve consensus for the acceptance of the plan. ${ }^{* 14}$ In light of situations of this nature, secured creditors should be voting in their own groups, for their rights and interests differ from the rights and interests of unsecured creditors.

At the same time, debtor-related creditors and other creditors voting in the same group may display a conflict of interests. In some cases, debtor-related creditors shall be given preference in the proceedings and thereby have an advantage over other creditors. Debtor-related creditors have readier access to financial reports that provide more information than is otherwise available about the debtor's actual economic situation, even though it has been pointed out that all creditors in the proceedings should be guaranteed the same information about the debtor's assets and obligations. ${ }^{* 15}$ Compared to other creditors, debtor-related

$8 \quad$ P. Varul. Pankrotiseaduse uued parandusettepanekud ['New proposals for amendments to the Bankruptcy Act']. - Juridica 2008/6, p. 362 (in Estonian).

9 T. Saarma. Pankrotimenetluse põhimõtted ['The principles of bankruptcy law']. - Juridica 2008/6, p. 354 (in Estonian).

10 UNCITRAL. Legislative Guide on Insolvency Law (see Note 7), p. 11.

$11 \quad$ T. Saarma (see Note 9), p. 355.

12 A. Kasak. Võlausaldajate võrdse kohtlemise põhimõttest kõrvalekaldumine pankrotimenetluses ['Deviations from the Principle of Equal Treatment of Creditors in Insolvency Proceedings']. Master's thesis. Tartu 2010, p. 16 (in Estonian).

13 European Commission. Best Project on Restructuring, Bankruptcy and a Fresh Start. Final Report of the Expert Group. September 2003. European Commission Enterprise Directorate General, p 52. Available at http://www.pedz.uni-mannheim. $\mathrm{de} / \mathrm{daten} / \mathrm{edz}-\mathrm{h} / \mathrm{gdb} / \mathrm{o} 3 /$ best-report-en.pdf (most recently accessed on 5.1.2014).

14 Saneerimisseaduse eelnõu seletuskiri ['Explanatory Notes to the Reorganisation Act'], p. 30. Available at http://www.riigikogu.ee $/$ ?page $=$ eelnou\&op $=$ ems2\&emshelp $=$ true\&eid $=401582 \& u=20130407192528($ most recently accessed on 5.1 .2014$)$ (in Estonian).

15 B. Wessels. Cross-Border Insolvency Law: International Instruments and Commentary. Kluwer Law International 2007, p. 649 . 
creditors have a different position. For example, they have a preferential right to important information. This might result in a situation wherein debtor-related creditors decide the conditions for transforming of other creditors' claims. Consequently, creditors should vote in separate groups because of this preferential position-since the treatment of creditors varies along these lines, debtor-related creditors should vote in different groups than other creditors are.

However, the formation of groups cannot take into account only the interests of creditors. After all, the objective of reorganisation is to enable debtors to overcome their economic difficulties. The debtor may form groups in such a way that the creditors would be likely to accept the plan. The Supreme Court stated in its ruling in case 3-2-1-122-09 that the interests of the debtor are somewhat more important in reorganisation proceedings than the interests of the creditors. The determinative factor is whether the creditors' interests are seriously infringed. ${ }^{* 16}$

The Supreme Court's statements regarding preference for the debtor's interests are reasonable. While it must be ensured at the same time that none of the creditors' interests are seriously violated, when, on the other hand, creditors do not take account of the debtor's interests, reorganisation is unsuccessful and the debtor ends up insolvent. Creditors may not be able to recover such large claims in bankruptcy proceedings as in reorganisation (especially in a situation wherein the debtor's only asset is pledged property). According to some studies, payments to creditors may be almost twice as large in reorganisation proceedings as in the case of sale in bankruptcy. ${ }^{*} 7$ While the payments tend to be larger, the debtor should still take into account the interests of the creditors in the various creditor groups, since it is their voting rights that allow the reorganisation to succeed.

The RA's conception of the idea of dividing creditors into groups proceeds from Chapter 11 of the U.S. Bankruptcy Code. ${ }^{*} 18$ According to the U.S. Bankruptcy Code ${ }^{* 19}$, a plan may place a claim in a particular group only if that claim or interest is substantially similar to the other claims or interests in the relevant group. This means that the formation should be based on the claims' nature. In the U.S. a claim shall be included in the group in question where the other claims covered by that group are substantially similar to it. ${ }^{*}{ }^{20}$

Other countries' legislation on the formation of creditor groups makes it compulsory to divide creditors into distinct groups for reorganisation proceedings. This is seen, for example, in German and Finnish insolvency law.

Pursuant to §222 (1) of the German Insolvenzordnung ${ }^{* 21}$ (InsO), in determination of the rights held by the parties involved with the insolvency plan, such creditor groups must be formed when the creditors differ in their legal statuses. A distinction shall be made among 1) those creditors entitled to separate satisfaction if their rights are encroached upon by the plan, 2) the non-lower-ranking creditors, and 3) each class of lower-ranking creditors involved in the insolvency proceedings unless their claims are deemed to be waived pursuant to §225. Additionally, creditors' economic interests should be taken into consideration in the formation of groups. Pursuant to Subsection 2 of the InsO's §222, creditors whose economic interests are similar shall be assigned to the same group. Obviously, regulation taking into account both the legal and the economic interests of the creditors in the forming of creditor groups ensures the protection of the creditors' interests more than does our own legal system, which does not make the formation of groups compulsory.

The Finnish Restructuring of Enterprises Act ${ }^{{ }^{2} 2}$ too (in §51 (3)) provides that creditors shall be divided into groups. That law prescribes that distinctions shall be drawn among secured creditors, creditors holding a floating charge as security for their claims, and other than secured creditors-so that one group is formed of creditors whose claims may be enforced without a judgement or court order.

16 CCSCr_18.11.2009,_3-2-1-122-09, para. 19. Available at http://www.riigikohus.ee/?id=11\&tekst=RK/3-2-1-122-09 (most recently accessed on 5.1.2014) (in Estonian).

17 P. Manavald. Economic crisis and the effectiveness of insolvency regulation. - Juridica International 2010 (XVII), p. 213.

18 Saneerimisseaduse eelnõu seletuskiri (see Note 14), p. 30.

19 USA Bankruptcy Code. Title 11 - Bankruptcy. Available at http://www.law.cornell.edu/uscode/usc_sup_01_11.html (most recently accessed on 5.1.2014).

20 Bankruptcy Code, Rules and Official Forms, 1992: Law School Edition. West Publishing Co. 1992, p. 328.

21 Insolvenzordnung vom 5. Oktober 1994. - BGBl. I, p. 2866 (in German).

22 'Laki yrityksen saneerauksesta', 1993/47. Available at http://www.finlex.fi/en/laki/kaannokset/1993/en19930047 (most recently accessed on 23.5.2014). 
It should be compulsory, in light of the examples given above, to form separate creditor groups in reorganisation proceedings for grouping of those who have different rights and interests for voting purposes. Therefore, Estonian reorganisation proceedings' regulation should be amended on the basis of other countries' legislation and guidelines of international organisations mentioned above. The law should provide that the debtor is obliged to define separate creditor groups for voting purposes. These groups should be formed in such a way that creditors with the same rights and interests would vote in the same group. For reduction of any further damage to creditors' interests, the creditors' common economic interests should also be taken into consideration. The RA should provide minimum requirements stating which creditors should be in different groups from each other. At least, there should be an obligation to form separate groups at least for secured and unsecured creditors, along with a group only for debtor-related creditors. The formation of groups increases legal certainty while at the same time ensuring the legitimacy of the voting and the protection of the parties' interests and rights in the reorganisation proceedings. This, in turn, leads to a situation wherein creditors will participate actively in the proceedings and the RA accomplishes its objective efficiently.

\section{Creditors to be defined as a separate group}

\subsection{Secured creditors}

Secured creditors have priorities established by the law in consideration of the nature and purpose of the pledge. According to $\$ 280$ of the Law of Property Act ${ }^{*} 3$ (LPA), secured creditors' claims are preferred above all other claims with respect to the pledged property. Reorganisation proceedings and the voting process shall also follow these priorities of secured creditors. However, under current implementing law, secured creditors' rights are not preferential in the manner required by this law.

Firstly, it must be recognised that the RA does not forbid the transformation of a secured claim as a reorganisation measure. Secured creditors can be involved in reorganisation and given the right to vote. However, according to rulings by the Civil Chamber of the Supreme Court, creditors involved in the reorganisation process cannot be left without their secured claim, where one exists. Secured rights shall not be transformed or changed. Since a mortgage does not presume the existence of a claim to be secured (LPA, $\S 325$ (4)), the claim secured on the transformation does not affect the validity of a mortgage. ${ }^{*} 4$ However, as the Supreme Court has stated, reorganisation proceedings cannot treat secured creditors with much less favour than that given them in bankruptcy proceedings. ${ }^{*} 5$

Nevertheless, secured creditors are treated in reorganisation as unsecured creditors, and they are in the same group as unsecured creditors for voting purposes. Such a regulatory approach harms the rights and interests of the secured creditors because they are not treated as priorities; in contrast, in bankruptcy proceedings, their preferential rights are ensured. According to $\$ 153$ (1) of the Bankruptcy Act ${ }^{{ }^{2} 6}$ (BA), secured creditors' claims are satisfied before all other claims. The RA does not specify such priority rights. Therefore, a situation arises in which secured creditors prefer bankruptcy proceedings to reorganisation, while the former are, in general, less favourable to the interests of unsecured creditors.

Moreover, it has been held that the parties' divergent interests mean that secured creditors almost always prefer quick sale of their security, while unsecured creditors prefer the amount realised for the sale of assets or the business. ${ }^{* 7}$ If the property is sold for as high a price as possible, unsecured creditors too can have their claims satisfied. In the case of a quick sale, the price is lower and only secured creditors may have their claim satisfied. In consequence, secured creditors have another reason to prefer the debtor's liquidation to reorganisation, for in liquidation they can rapidly recover most or all of their investment. There may be advantages for secured creditors if the debtor is declared bankrupt. It has been pointed out that banks

23 Asjaõigusseadus. - RT I 1993, 39, 590; RT I, 23.4.2012, 1 (in Estonian).

24 CCSCr 9.5.2011, 3-2-1-25-11, para. 59; CCSCr 19.6.2013, 3-2-1-74-13, para. 18. Available at http://www.riigikohus. ee/?id=11\&tekst=RK/3-2-1-74-13 (most recently accessed on 5.1.2014) (in Estonian).

25 CCSCr 9.5.2011, 3-2-1-25-11, para. 61; CCSCr 19.6.2013, 3-2-1-74-13, para. 19.

26 Pankrotiseadus. - RT I 2003, 17, 95; RT I, 23.12.2013, 1 (in Estonian).

27 The World Bank. Effective Insolvency Systems: Principles and Guidelines. October 200o, p. 22. Available at http://www1. worldbank.org/finance/assets/images/DL_2_2_consultation.pdf (most recently accessed on 14.5.2014). 
and similar lenders often may be able to recover a greater percentage of their claim if the debtor is liquidated. ${ }^{* 28}$ Reorganisation may delay realising the security of secured creditors. ${ }^{*}{ }^{29}$

As is noted above, many other countries' legal acts and also international organisations provide that secured creditors shall be divided into groups for voting purposes. For instance, the German InsO ( $\$ 222(1)$ ) and the Finnish Restructuring of Enterprises Act ( $\left.\$_{51}(3)\right)$ prescribe that secured creditors shall be divided into separate groups.

Accordingly, if a secured creditor's claim is not fully secured, the unsecured part of the claim shall not be treated as a secured claim. Among the guidelines for distinguishing between creditors with different rights are those provided by UNCITRAL: If the value of the secured property is not sufficient to satisfy the secured creditor, the secured creditor shall participate in the proceedings as an unsecured creditor. ${ }^{*} 30$ The creditor has a preferential right only with respect to the portion of the claim that is secured. The unsecured part can be treated in the same way as other unsecured claims because there is no preferential right. For avoidance of unnecessary court actions, this principle should be set forth clearly in the RA.

In bankruptcy proceedings, compromise refers to an agreement that is similar to that in reorganisation wherein the debtor and creditors reach a compromise with respect to the payment of debts (BA, $\S 178$ (1)). Compromise in bankruptcy proceedings calls into play special regulation for secured creditors for voting purposes. According to $\S 181$ of the BA, a creditor whose claim is secured by a pledge shall vote on a compromise only if the claim is not fully secured by the pledge. In such a case, the claim of the pledgee shall be taken into account in voting only to the extent that the claim would presumably not be satisfied from the proceeds of the sale of the pledged object. If there is a request for the invocation of a claim arising from the right of security of a creditor who is the pledgee to be precluded for more than 90 days by a compromise proposal, the claim of the creditor who is the pledgee shall be fully taken into account in the voting.

Both the nature and the purpose are similar between reorganisation and bankruptcy proceedings. It cannot be the legislator's will for secured creditors' interests to be protected less in reorganisation than in bankruptcy proceedings. Such a situation cannot be justified. The position of the pledgee in reorganisation proceedings needs to be strengthened. For better protection of the secured creditors' rights in the proceedings to be ensured, forming a separate group of secured creditors should be considered.

\subsection{Debtor-related creditors}

Debtors should arrange a different group for related creditors for voting purposes in reorganisation proceedings because, when compared to other creditors, these creditors have different rights and interests. However, the RA does not differentiate between creditors who are related to debtors and other creditors.

According to UNCITRAL, a debtor-related person may be i) a person who is or has been in a position of control of the debtor or ii) a parent, subsidiary, partner, or affiliate of the debtor. ${ }^{*}{ }^{31}$ The Estonian insolvency system does not provide general regulation and case law stating what the legal status of debtor-related persons should be. In definition of the class of debtor-related creditors, therefore, $\$ 117$ of the BA should be followed. It provides a list of persons connected with natural and legal persons. However, that list is not exhaustive-in Subsection 3 of the same section, the BA states that a court may consider a person who is close to a debtor to be a debtor-related person even if that person is not specified in Subsection 1 or 2.

A clear distinction should be made between ordinary and subordinated creditor claims. As has been noted in the legal literature, a subordinated loan is usually defined as a loan that is repayable after the claims of all other creditors have been covered. ${ }^{*}{ }^{2}$ It is the opinion of the Ministry of Justice that the status of partners/shareholders or other debtor-related persons differs from that of other creditors. On the basis of economic content, their loan should be treated as increasing the share capital. Therefore, the loan cannot be treated as commensurate with other claims in reorganisation and bankruptcy proceedings. The claim shall be satisfied only after all other creditors' claims have been covered. Treating the claims

28 J. Sarra. Creditor Rights and the Public Interest: Restructuring Insolvent Corporations. Canada: University of Toronto Press Incorporated 2003, p. 59.

29 Ibid., p. 58.

3o UNCITRAL. Legislative Guide on Insolvency Law (see Note 7), p. 275.

31 Ibid., p. 6.

32 A.Vutt. Subordination of shareholder loans in Estonian law. - Juridica International 2008 (XV), p. 87. 
equally may constitute an abuse of the other creditors' rights, and it reduces the 'ordinary' creditors' trust in reorganisation. ${ }^{*} 33$

Section 222 of the German InsO prescribes that the formation of different group for subordinated creditors must be addressed in an insolvency plan. The interests of subordinated creditors (nachrangige Insolvenzgläubiger) are to be addressed after all unsecured creditors have been paid in full. Subsection 3 of that section states exceptions to this requirement-a separate group may be formed for minor shareholders whose share in the liable capital amounts to less than one per cent or to less than one 1,00o euros.

On the other hand, the debtor can ensure the acceptance of the reorganisation plan through debtor-related persons. In the event of approval of the reorganisation plan, the debtor has an opportunity to continue its business activities, and its partners/shareholders are more likely to earn some money. If the creditor groups are formed in that way, the creditors largely support the approval of the plan, and then there is less chance of the plan not being accepted. Among the results is that the creditors and the debtor attempt to increase the number of their votes, in order to control the reorganisation process as has been declared in the literature. ${ }^{*}{ }^{34}$

Debtor-related persons and other creditors voting in the same group may act against the principle of good faith. The principle of good faith is prescribed in $\$ 138$ of the General Part of the Civil Code Act ${ }^{*} 35$ and in $\S 6$ of the Law of Obligations Act ${ }^{*} 36$ (LOA). According to the former (in §138(1)), rights shall be exercised and obligations performed in good faith. The act goes on to prescribe, in Subsection 2, that a right shall not be exercised in an unlawful manner or with the objective of causing damage to another person. According to the legal literature, for purposes of ascertaining whether the rights in question have been abused, the parties' behaviour should be evaluated for whether it is fair and equitable. ${ }^{*} 3$

Therefore, a situation may be created wherein debtor-related creditors participate in the proceedings and abuse their rights in order to obtain control over the proceedings. Creditors may submit a claim that is void because of the ostensible transaction. Furthermore, money can be taken out with these claims and other creditors' interests may be harmed. However, according to §200 (1) of the Code of Civil Procedure 38 (CCP), participants in proceedings are required to exercise their procedural rights in good faith.

In Estonian judicial practice, disputes have arisen with respect to debtor-related persons participating in voting. The practice, regrettably, has not been uniform.

The Supreme Court found in its ruling on case 3-2-1-122-09 that the RA does not distinguish between debtor-related creditors and other creditors. Under the RA ( $\$ 24(2)$ ), the number of votes for each creditor is proportional to the amount of the creditor's principal claim, which shall have been ascertained pursuant to said legal act. According to the court, the BA similarly does not distinguish between debtor-related creditors and other creditors. ${ }^{*} 9$ However, neither this silence nor the above statement can be a reason that debtor-related and other creditors should vote in the same group in both reorganisation and bankruptcy proceedings.

Pärnu County Court approved a reorganisation plan in its decision 2-09-21196. In this case, the bank as a secured creditor submitted an application to a court in which it was requested that approval of the reorganisation plan be refused because, on the basis of the reorganisation plan, the bank would be treated substantially less favourably than were other creditors, who were related to the debtor. The bank was of the opinion that it would not be acceptable if the debtor-related creditors, who held two-thirds of all the votes represented, were to decide on the transformation of the secured creditor's claim. The court criticised the bank, noting that the creditor's action was the reason for which the debtor had had to submit the reorganisation petition in the first place. The County Court found that, since reorganisation and bankruptcy proceedings have different objectives, relatedness in the case of some debtor-related persons has no legal effect and that, unlike in bankruptcy proceedings, relatedness does not mean that violation of other creditors' rights should automatically be presumed. ${ }^{*} 40$

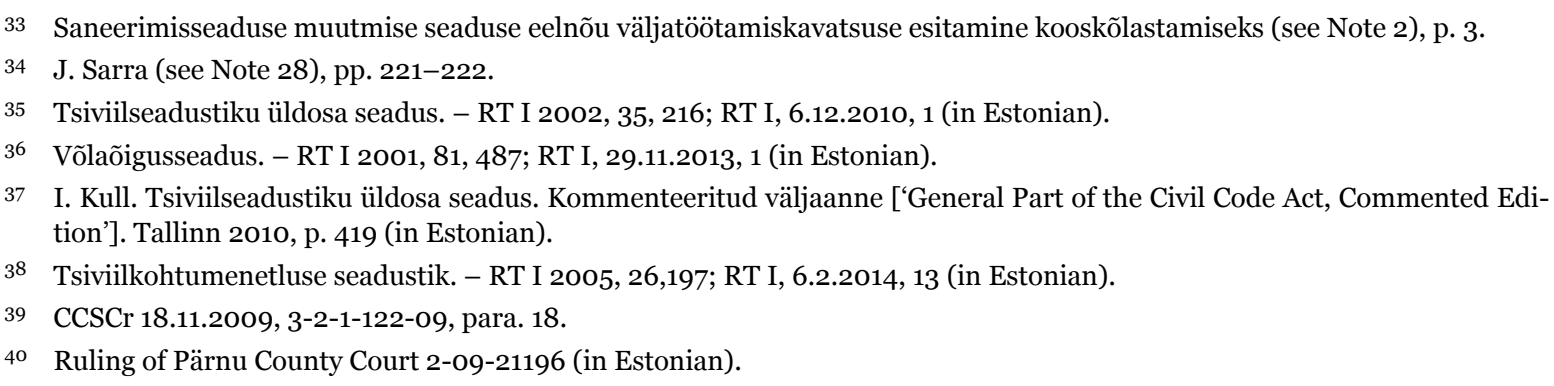


Harju County Court found in its ruling on case 2-09-12156 that debtor-related creditors shall be separated out into their own group. The court analysed the principle related to equal treatment of creditors and found the following: a situation in which there are secured and unsecured creditors as well as debtor-related creditors and they are not divided into separate groups even though the measures of debt transactions are different runs counter to the purpose of reorganisation, since the creditors have different rights. The court found that debtor-related creditors should belong to a separate group from other creditors and that the votes of the debtor-related persons cannot be the determining factor in the transformation of other creditors' claims. The court noted that the purpose of the creditor groups is to ensure that creditors with the same interests and rights are treated equally. Debtor-related persons clearly have the same interests in general, which distinguish them from other creditors. ${ }^{*} 11$

Although the legislator has prescribed legal remedies for creditors, the practice is not uniform and does not always take into account the objective of the formation of creditor groups. According to $\$ 16$ (2) of the RA, the duty of a reorganisation adviser, inter alia, is to verify the lawfulness of creditors' claims. Section 43 prescribes, in Subsection 1, that the court terminates reorganisation proceedings under the following conditions: it becomes evident that there is actually no claim against the debtor for which transformation is requested by a reorganisation plan, the amount of the claim is unclear, the reorganisation adviser cannot determine the lawfulness of the claim, or the claim is not substantiated. Furthermore, creditors may file an application to raise an objection pertaining to the approval of the reorganisation plan. According to $\S 26$ of the RA, a creditor may, within the term specified in the same act's $\$ 10$ (2) 3), submit a reasoned application to a court in which he or she requests that approval of the reorganisation plan be refused if 1 ) he or she has voted against the reorganisation plan; 2) his or her rights have been seriously violated in the course of the preparation of the reorganisation plan or in the plan's acceptance; or 3) on the basis of the reorganisation plan, he or she is treated substantially less favourably than other creditors or relative to other creditors belonging to his or her group.

However, the provisions do not protect the parties' rights and interests sufficiently. Instead, these claims might lead to court actions and, therefore, may not ensure safeguarding of the principle of speed and efficiency of the proceedings. ${ }^{*} 2$ Consequently, the legislator should amend the law and make the formation of creditor groups mandatory. In order to ensure the legitimacy of the voting and also guarantee legal certainty and legal clarity, debtor-related persons should be voting in different groups from other creditors.

On the other hand, it is not always justified to form separate groups of debtor-related creditors when their transactions are real and legitimate. Therefore, in each case, the relationship between the parties and the economic substance of the transaction should be verified. If the transaction does not go against the principle of good faith and equal treatment of creditors, and the debtor has had consideration, there is no reason to form a separate group. In this case too, the principle of forming a separate group of creditors with the same rights is also followed. It is when there are subordinated claims and other debtor-related creditor claims not involving the same legal status and interests as the other unsecured claims that a separate group from other creditors should be created.

\section{Conclusions}

The issue of formation of creditor groups for voting purposes arises in relation to the adoption of a reorganisation plan. Reorganisation is a set of measures implemented in order to enable the debtor to overcome the economic difficulties experienced. Since the debtor's reorganisation plan is of determinative importance for the further economic activity of said business, the debtor might manipulate the votes and affect the adoption of the plan, which could violate creditors' rights and interests. In order to ensure the legality of the voting, it is justified to set up groups of creditor where those in each group have different rights and interests from those in the others.

In a comparison to the legislation of other states discussed in this article, the Estonian reorganisation law is one of the few national laws in its sphere that do not provide clear regulations on the formation of

41 Ruling of Harju County Court 2-09-12156 (in Estonian).

42 M. Schihalejev. Häälte määramine ja selle kohtulik järelevalve maksejõuetusmenetluses ['Determination of Votes and Its Supervision Exercised by Courts in Insolvency Proceedings'], pp. 29-33. Master's thesis. Tartu 2013 (in Estonian). 
separate creditor groups and do not generate associated judicial practice. However, the formation of different creditor groups is essential if the legislator is to ensure legal certainty and an effective reorganisation law. Examination of the practice of other states as discussed above reveals no evidence that forming groups is not justified. On the contrary, all of the states considered prescribe that formation of creditor groups is compulsory when the creditors have disparate rights and interests, in order to ensure the equal treatment of those creditors with the same legal status. Therefore, there is justification for the opinions expressed by the Estonian Ministry of Justice in its Submission for Approval of the Plan of Developing the Draft Act on Amending the Reorganisation Act about amendments to the RA.

The legislator should prescribe clear rules and provisions in the RA stating that the debtor should form creditor groups for voting purposes in reorganisation proceedings when the creditors differ in their legal status and economic interests. The RA should provide minimum requirements that determine which creditors should be voting in their own groups. Secured and unsecured creditors should be assigned to different groups. However, a creditor has a preferential right only to the extent to which the claim is secured. Debtorrelated creditors too should vote in a separate group, especially in the case of subordinated claims. In cases involving other debtor-related creditors' claims, verification should be obtained in each case as to whether they have the same legal status and interests as the other unsecured creditors, such as would justify voting in the same group as those others. 